\title{
Formation of Biofilms and Biocorrosion on AISI-1020 Carbon Steel Exposed to Aqueous Systems Containing Different Concentrations of a Diesel/Biodiesel Mixture
}

\author{
Ivanilda Ramos de Melo, ${ }^{1}$ Severino Leopoldino Urtiga Filho, ${ }^{2}$ \\ Fernando Jorge Santos Oliveira, ${ }^{3}$ and Francisca Pessoa de França ${ }^{1}$ \\ ${ }^{1}$ Escola de Química, Universidade Federal do Rio de Janeiro, Avenida Athos da Silveira Ramos 149, Bl E, Sl E-109, \\ 21941-909 Rio de Janeiro, RJ, Brazil \\ ${ }^{2}$ Departamento de Engenharia Mecânica, Universidade Federal de Pernambuco, Avenida Professor Moraes Rego 1235, \\ Cidade Universitária, 50670-901 Recife, PE, Brazil \\ ${ }^{3}$ Gerência de Meio Ambiente, Petróleo Brasileiro SA, Avenida Almirante Barroso 81, 23 Andar, 20031-004 Rio de Janeiro, RJ, Brazil
}

Correspondence should be addressed to Francisca Pessoa de França, fpfranca@eq.ufrj.br

Received 5 July 2011; Revised 8 September 2011; Accepted 9 September 2011

Academic Editor: Flavio Deflorian

Copyright (C) 2011 Ivanilda Ramos de Melo et al. This is an open access article distributed under the Creative Commons Attribution License, which permits unrestricted use, distribution, and reproduction in any medium, provided the original work is properly cited.

\begin{abstract}
Environmental and economic concerns accelerated biofuels research and industrial production. Many countries have been using diesel and biodiesel blends as fuels justifying research on biofilms formation and metals corrosion. Cylinders made of AISI-1020 carbon steel with an exposed area of $1587 \mathrm{~mm}^{2}$, water, and water associated with B3 fuel (diesel/biodiesel blend at $97: 3 \mathrm{v} / \mathrm{v}$ ) were used.The formation of biofilms was detected, and biocorrosion was detected on AISI-1020. The results showed a variation in sessile microflora during the experiments. In the biofilms, a significant concentration of aerobic, anaerobic, IOB, Pseudomonas aeruginosa, and sulfate-reducing bacteria was observed. The corrosion rates varied between $0.45 \pm 0.01 \mathrm{and} 0.12 \pm 0.01 \mathrm{~mm} / \mathrm{year}$, depending on the experimental conditions. The main corrosion products identified were various forms of $\mathrm{FeOOH}$, magnetite, and all forms of FexSy. In systems where there were high levels of sulfate reducing bacteria, corrosion pits were observed. In addition, the aliphatic hydrocarbons present in the fluid containing 10\% B3 were totally degraded.
\end{abstract}

\section{Introduction}

Metal corrosion associated with the use of biofuels is a new field of research, and this study aims to elucidate the involvement of microorganisms in this process.

Several factors, such as environmental issues, energetic sustainability, and excessive consumption of petroleum products, have resulted in the rapid search for alternative fuels in recent years. The need to decrease dependence on nonrenewable fuels derived from petroleum and to reduce pollution caused by burning these fuels has accelerated the search for alternative energy sources, such as biofuels.

Biodiesel can be chemically defined as a mixture of monoalkyl esters obtained from long-chain fatty acids. Because biodiesel can be mixed with diesel in any proportion, binary mixtures of diesel/biodiesel can be used as fuel. Diesel fuel is a fuel derived from oil, and consists essentially of paraffinic, olefinic, and aromatic compounds.

Several studies are underway to test different types of fuel made from pure transesterified oils and those mixed with petroleum diesel in different proportions. Such fuels have shown good results when tested in the diesel engines of buses, trucks, tractors, and electric generators [1]. There have been reports in the literature that wear originating from metal contacts in any mechanical system is reduced in diesel cycle engines when biodiesel is added. Some studies on the corrosive effects of diesel/biodiesel mixtures have recently been published, but it is widely believed that biodiesel acts as a lubricating additive in diesel engines, increasing engine life. However, further studies are needed, especially to develop 
techniques for the rapid assessment of corrosive processes in media with low conductivity.

The presence of water and microorganisms in fuel can induce changes in its properties over time due to hydrolytic, microbial, and oxidative reactions. Corrosion and degradation processes can be accelerated by these factors. So the study of corrosion is important to prevent the loss and collapse of metallic materials used to construct pipelines and storage tanks.

Carbon steel is composed of an iron-carbon alloy, which contains less than $2 \%$ carbon and some residual elements in small concentrations, such as silicon, phosphorus, and sulfur. This material has been principally used in the construction of pipelines for the transportation of fuels. Metal corrosion occurs due to chemical or electrochemical interactions between the metal and the aqueous medium, which results in the formation of corrosion products and the liberation of energy $[2,3]$. The corrosive processes associated with the use of diesel/biodiesel mixtures is particularly relevant, especially when it is associated with the possible damage caused by the corrosion and degradation of biofuels from production to storage and distribution.

In light of the above, the objective of this study was to evaluate the formation of biofilms and their effects on AISI-1020 carbon steel in a dynamic system containing fresh water as the working fluid with $10 \%, 30 \%$, and $60 \% \mathrm{~B} 3$ fuel (diesel/biodiesel $97: 3 \mathrm{v} / \mathrm{v}$ ).

\section{Materials and Methods}

2.1. Metallic Cylinders and Equipment. Cylinders made of AISI-1020 carbon steel with an exposed area of $1587 \mathrm{~mm}^{2}$ (internal diameter: $50 \mathrm{~mm}$, length: $10 \mathrm{~mm}$ ) were used. The cylinders were blasted with glass beads, chemically treated in the manner described by Torres and de França [4], and weighed before being placed in the system.

The experiments were conducted in a looping system, which is illustrated in the schematic shown in Figure 1. Fresh water supplemented with different amounts of B3 fuel was used as the circulating fluid. The B3 fuel, which was used in Brazil from July 2008 to July 2009, consists of a mixture of diesel and biodiesel in the proportions of $97: 3(\mathrm{v} / \mathrm{v})$. Actually, B5 fuel is used in Brazil, a mixture of diesel and biodiesel in the proportions of 95:5 (v/v).

The experiments were conducted with circulating fluids composed of fresh water and water containing B3 at concentrations of $10 \%, 30 \%$, and $60 \%$. The respective mixtures were transferred to the reservoir of the looping system (Figure 1), which is made from $316 \mathrm{~L}$ stainless steel with a flow rate of $1 \mathrm{~L} / \mathrm{s}$. It was used a Willy analog manometer coupled to a WTP series 4010 pressure transmitter to record pressure measures. During the tests, the measured pressures were about $1 \mathrm{psi}$, which corresponds to $0.07 \mathrm{kgf} / \mathrm{cm}^{2}$. Fluid temperatures were not controlled in order to reproduce field conditions during biofuels transportation through industrial pipelines, and a variation between 35 and $45^{\circ} \mathrm{C}$ was observed.

2.2. Microbial Quantifications. Planktonic microorganisms were measured only at the beginning of the experiment,

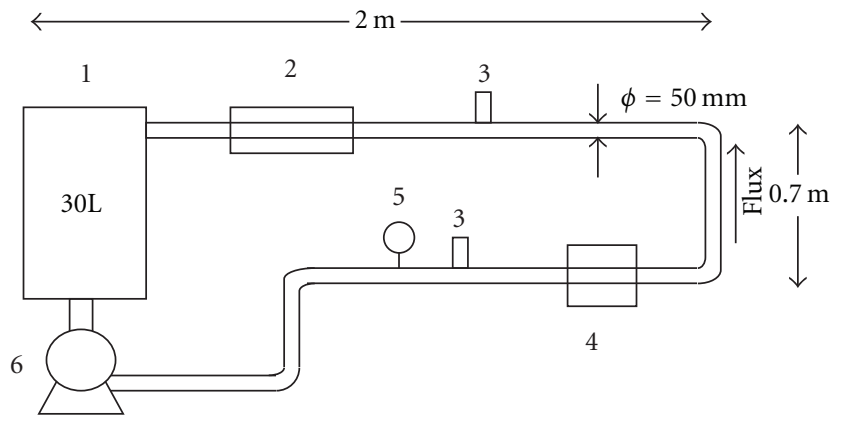

FIGURE 1: Looping diagram. (1) Reservoir containing the fluid; (2) support for the cylinders; (3) thermocouple; (4) flow meter; (5) pressure sensor; (6) centrifugal pump.

and, at the end of each experiment, only sessile microorganisms were measured. To measure the microorganisms, the cylinders were placed in vials containing a reducing solution, and the biofilm was removed by scraping with a sterile spatula. The composition of the reducing solution was (in $\mathrm{g} / \mathrm{L}$ ): sodium thioglycollate $0.124,2.5$ yeast extract, ascorbic acid, and sodium chloride 8.5. Four milliliters of a $0.025 \% \mathrm{~m} / \mathrm{m}$ resazurin solution was added and completed with $1000 \mathrm{~mL}$ of distilled water. The reducing solution was purged with $\mathrm{N}_{2}$ in order to obtain an anaerobic condition and stored in sealed vials. The $\mathrm{pH}$ was reached to $7.2 \pm 0.2$, and vials were sterilized at $121^{\circ} \mathrm{C}$ for 15 minutes. Under that condition, the redox potential of the solution was approximately $-100 \mathrm{mV}$. To quantify the amount of aerobic microorganisms, a saline solution of $0.85 \% \mathrm{NaCl}$ was used to dilute the microorganisms. To quantify the amount of aerobic microorganisms, a saline solution of $0.85 \% \mathrm{NaCl}$ was used to dilute the microorganisms [4].

The total amount of aerobic bacteria (AB) and fungi (TF) were quantified by counting the colony forming units (CFUs) with the pour plate technique. Plate count agar and potato dextrose agar (Merck, Darmstadt, Germany) were used for bacterial and fungi counting, respectively. The number of CFU was determined after incubation for 48 hours and 120 hours for bacteria and fungi, respectively. The total amount of anaerobic bacteria (ANB) was quantified with the most probable number technique (MPN) in the liquid medium thioglycolate (Merck, Darmstadt, Germany) purged with $\mathrm{N}_{2}$ after 21 days of incubation. The sulphate reducing bacteria (SRB) were quantified with the MPN technique in a modified Postgate E medium [5] and purged with $\mathrm{N}_{2}$ after 21 days of incubation. Pseudomonas aeruginosa was quantified by counting the number of CFU in a cetrimide agar medium (Merck, Darmstadt, Germany) with the pour plate technique after 48 hours of incubation at $35 \pm 1^{\circ} \mathrm{C}$. The iron oxidizing bacteria (IOB) were also quantified by the pour plate technique with a medium containing ferric ammonium citrate [6] after 15 days of incubation. The amount of acid producing aerobic bacteria (APAB) was determined by MPN technique using red phenol medium (Acumedia Manufactures, Mich, USA), supplemented with $1 \%$ sucrose, $48 \mathrm{~h}$ of incubation at $35 \pm 1{ }^{\circ} \mathrm{C}$. The amount of acid producing anaerobic bacteria (APANB) was determined 
TABLE 1: Planktonic microorganisms in the fluids used in the process.

\begin{tabular}{lcccc}
\hline Microorganism & Water & Water $+10 \%$ B3 fuel & Water $+30 \%$ B3 fuel & Water $+60 \%$ B3 fuel \\
\hline AB $(\mathrm{CFU} / \mathrm{mL})$ & $5.3 \times 10^{7}$ & $4.8 \times 10^{4}$ & $3.6 \times 10^{7}$ & $4.9 \times 10^{10}$ \\
IOB $(\mathrm{CFU} / \mathrm{mL})$ & $9.2 \times 10^{3}$ & $6.4 \times 10^{5}$ & $1.2 \times 10^{7}$ & $5.0 \times 10^{5}$ \\
SRB $(\mathrm{MPN} / \mathrm{mL})$ & $\mathrm{ND}$ & $9.5 \times 10^{4}$ & $1.4 \times 10^{5}$ & $1.4 \times 10^{5}$ \\
ANB $(\mathrm{MPN} / \mathrm{mL})$ & $0.4 \times 10^{1}$ & $1.4 \times 10^{10}$ & $1.4 \times 10^{10}$ & $2.9 \times 10^{9}$ \\
TF $(\mathrm{UFC} / \mathrm{mL})$ & $\mathrm{ND}$ & $2.0 \times 10^{1}$ & $1.9 \times 10^{2}$ & $3.7 \times 10^{2}$ \\
APAB $(\mathrm{MPN} / \mathrm{mL})$ & $0.9 \times 10^{1}$ & $4.5 \times 10^{3}$ & $2.0 \times 10^{3}$ & $2.5 \times 10^{2}$ \\
APANB $(\mathrm{MPN} / \mathrm{mL})$ & $0.9 \times 10^{1}$ & $1.5 \times 10^{3}$ & $1.5 \times 10^{4}$ & $1.6 \times 10^{6}$ \\
P. aeruginosa $(\mathrm{CFU} / \mathrm{mL})$ & $2.9 \times 10^{3}$ & $3.5 \times 10^{3}$ & $2.6 \times 10^{4}$ & $4.6 \times 10^{3}$ \\
\hline
\end{tabular}

by same method described for quantification of APAB; but liquid media was purged with $\mathrm{N}_{2}$, and flasks were incubated for 21 days. Incubation procedures were done at $35 \pm 1{ }^{\circ} \mathrm{C}$ irrespective of studied microbial group.

2.3. Weight Losses and Corrosion Rate. The mass loss of the cylinders was quantified after 15 days. The method used included acid pickling with $\mathrm{HCl} 26 \%(\mathrm{v} / \mathrm{v})$, followed by neutralization with $\mathrm{NaOH} 10 \%(\mathrm{w} / \mathrm{v})$, then washing with distilled water, and degreasing with isopropyl alcohol and acetone. After drying in a vacuum oven model MA$030(150 \mathrm{mmHg})$ for 30 minutes at $70^{\circ} \mathrm{C}$, cylinders were transferred to a desiccator and subsequently weighed on an analytical balance.

The corrosion rate was obtained from

$$
\text { Corrosion rate }=\frac{w_{i}-w_{f}}{A \cdot t(\text { day } / \text { year }) \cdot D},
$$

where $w_{i}$ is initial weight; $w_{f}$ final weight; $A$ area of the cylinder; $D$ density of carbon steel $\left(0.00786 \mathrm{~g} / \mathrm{mm}^{3}\right) ; t$ exposure time.

2.4. X-Ray Diffraction, Scanning Electron Microscope, and Chromatography Assays. The corrosion products formed on the surface of the cylinders were dried at $45^{\circ} \mathrm{C}$ and analyzed with $\mathrm{X}$-ray diffraction in a Rigaku equipment coupled to a $\mathrm{Cu}$ source of $40 \mathrm{kV}$ and $20 \mathrm{~mA}$ current.

For scanning electron microscope (SEM) measurements, the cylinders were immersed in a fixative solution of $5 \%$ glutaraldehyde in a sodium cacodylate buffer $0.1 \mathrm{M}$ and maintained at $30^{\circ} \mathrm{C}$ for 24 hours. After the fixation step, three consecutive washes were performed with sodium cacodylate buffer $0.1 \mathrm{M}$. The cylinders were then dehydrated using ethanol at increasing concentrations (30-100\%) and coated with gold. The visualization was performed with an environmental SEM, model FEI Quanta 200 [7].

Previously to chromatography assays, fluid samples were treated by liquid-liquid extraction with analytical grade dichloromethane, according to procedures described by Miranda et al. [8]. Chromatography analyses were performed to verify the possible biodegradation of diesel present in the mixtures. It was used a gas chromatograph coupled to mass spectrometer (Shimadzu Europe GC/MS, model QP5050A), equipped with a Valcobond VB-5 column (30 m length $\times 0.25 \mathrm{~mm}$ diameter $\times 0.25 \mu \mathrm{m}$ thickness), under the following conditions: injector temperature: $290^{\circ} \mathrm{C}$; interface temperature: $280^{\circ} \mathrm{C}$; injection mode: split; carrier gas: helium; column internal pressure: $52.8 \mathrm{kPa}$; column flow: $1 \mathrm{~mL} / \mathrm{min}$; linear velocity: $36.3 \mathrm{~cm} / \mathrm{s}$; split ratio: 48 ; total flow: $50 \mathrm{~mL} / \mathrm{min}$; initial temperature programming: $50^{\circ} \mathrm{C}$ for 2 minutes; variation: $6^{\circ} \mathrm{C}$ per minute until reaching $280^{\circ} \mathrm{C}$ and stabilized for 20 minutes; mass spectrometer scan time: 3 minutes to 60.37 minutes; sweep: $40 \mathrm{~m} / \mathrm{z}$ to $350 \mathrm{~m} / \mathrm{z}$.

\section{Results and Discussion}

Table 1 shows the results of the initial measurements of the planktonic microorganisms in water and in the mixtures of water $+\mathrm{B} 3$ fuel at the beginning of each experiment. The fluids under study facilitate nutrients transport to the metal probes surface favoring microbial adhesion. In water, the growth of SRB was not observed. However, when the water was mixed with fuel, significant quantities of SRB were observed. It should be noted that there was an increase of all groups of microorganisms in the mixtures, which indicates that the fuel was contaminated.

SRBs have the ability to reduce sulfates via dissimilatory to generate energy for biosynthesis reactions related to their growth and maintenance, with the production of hydrogen sulfide $\left(\mathrm{H}_{2} \mathrm{~S}\right)$. These are heterotrophic and strictly anaerobic bacteria, but, despite this condition, they are able to tolerate the presence of oxygen in extreme environmental conditions $[9,10]$. SRBs stand out because the biocorrosive process they mediate is not only associated with biofilm formation, but also with the production of metabolites, such as biogenic $\mathrm{H}_{2} \mathrm{~S}$, that causes serious environmental and corrosion problems during the processing and storage of petroleum and derivatives.

Figure 2 shows the microbiota that have adhered to the cylinders after 15 days of operation. It may be noted that the number of microorganisms varied in the four systems, which is probably due to the differences into availability of nutrients. In addition, the adherence of a significant amount of SRB in the system containing the greatest concentration of fuel is worth noting. Bacteria are considered early colonizers of inanimate surfaces in natural and synthetic environments. Most investigations of microbiologically influenced corrosion are directed toward the behavior of biofilms that consist of pure or mixed cultures [11]. 


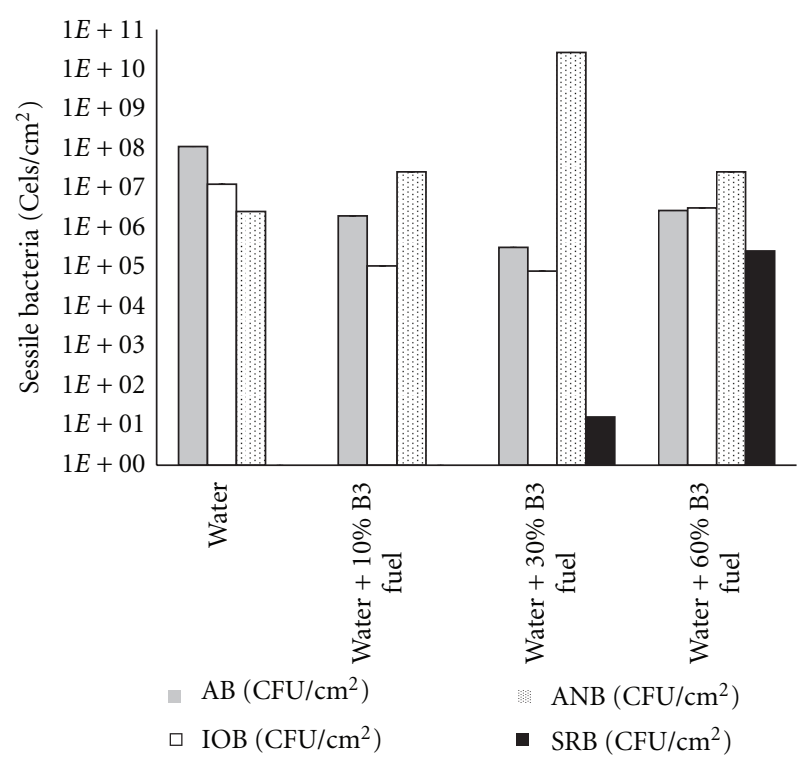

Figure 2: Sessile microorganisms in AISI-1020 carbon steel after 15 days under a flow of $1 \mathrm{~L} / \mathrm{s}$ of water and mixtures of water $+\mathrm{B} 3$ fuel at concentrations of $10 \%, 30 \%$, and $60 \%$.

Table 2 shows the corrosion rates calculated after 15 days. The corrosion rate is a parameter of great importance, because it provides information on the intensity and severity of the deterioration process of a particular system.

The data in Table 2 show that water was especially corrosive, probably due to the large amount of adhered IOB (on the order of $10^{6} \mathrm{cells} / \mathrm{cm}^{2}$ ). Iron oxidizing bacteria are gram negative and microaerobic, which allows them to actuate in the corrosion process via the oxidation of ferrous ion, which attacks the metallic material to form ferric ions to give rise to structures known as tubercles increasing metals corrosion [12].

Ambrozin et al. [13] believe that diesel/biodiesel mixtures are less corrosive than diesel fuel alone. Diesel containing sulfur compounds may promote more intense corrosion, especially in the presence of microorganisms like SRB. It was observed that the corrosion rates decreased as the amount of biofuel in the system increased, which demonstrates a protective effect on the material despite the presence of SRB and IOB, microorganisms that accelerate the corrosion process. One explanation for this phenomenon may be related to the presence of Pseudomonas aeruginosa in the biofilms. Studies are underway to evaluate the ability of the exopolysaccharides produced by these bacteria to inhibit the corrosion process [14, 15]. Quantification of Pseudomonas aeruginosa was performed, and significant amounts were encountered in the biofilms on the surface of the metals exposed to the fuel (Figure 3 ).

When analyzing the corrosion products formed on the surface of the cylinders, after exposure for 15 days with $\mathrm{X}$-ray diffraction (XRD), it was possible to identify iron oxide hydrates (Akaganeíta, Goethita, and Lepidocrocita), magnetite, and all forms of FexSy (Mackinwita, Jarosita, Pirotita, and Greigita) in the experiments. Figure 4 presents
TABLE 2: Corrosion rates as a function of the B3 fuel concentrations.

\begin{tabular}{lc}
\hline Fluids & Corrosion rate $(\mathrm{mm} /$ year $)$ \\
\hline Water & $0.45 \pm 0.01$ \\
Water $+10 \%$ B3 fuel & $0.35 \pm 0.05$ \\
Water $+30 \%$ B3 fuel & $0.14 \pm 0.02$ \\
Water $+60 \%$ B3 fuel & $0.12 \pm 0.01$ \\
\hline
\end{tabular}

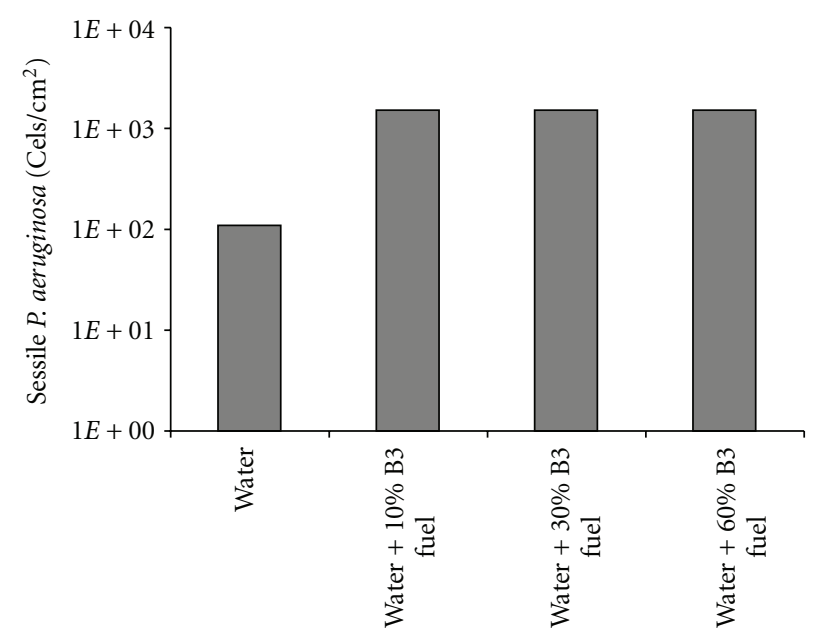

FIgure 3: Quantification of sessile Pseudomonas aeruginosa on the AISI-1020 carbon steel after 15 days of experimentation.

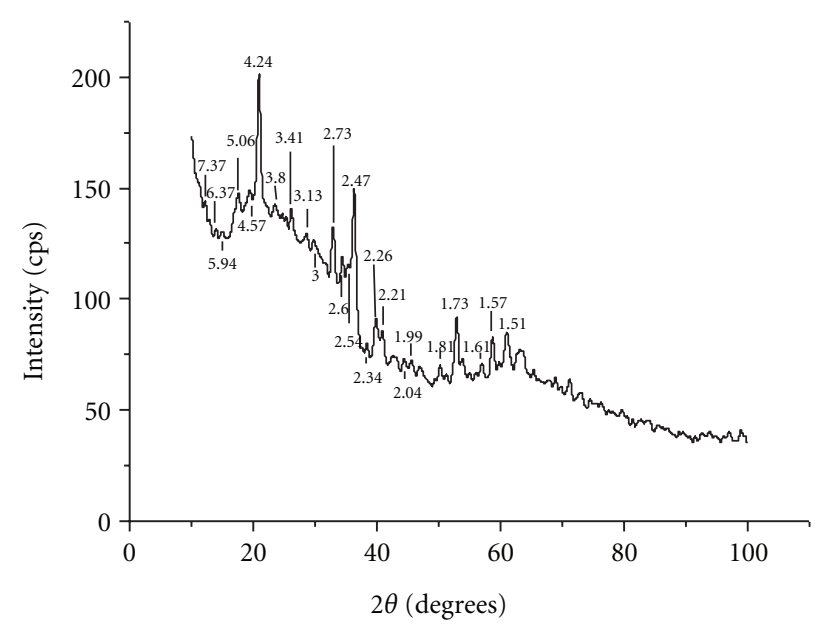

FIGURE 4: X-ray diffractogram of the products formed after the cylinders were exposed to the water $+10 \%$ B3 fuel for a period of 15 days.

the XRD measurements corresponding to the experiments conducted with the $10 \%$ B3 fuel.

Goethite and Lepidocrocite are the main crystalline phases in the composition of rust, which is a complex mixture of various crystalline phases of iron oxides and hydroxides that approximately correspond to the global formula $\mathrm{FeOOH}$. These phases are primarily responsible for the reddish-brown color [16]. 


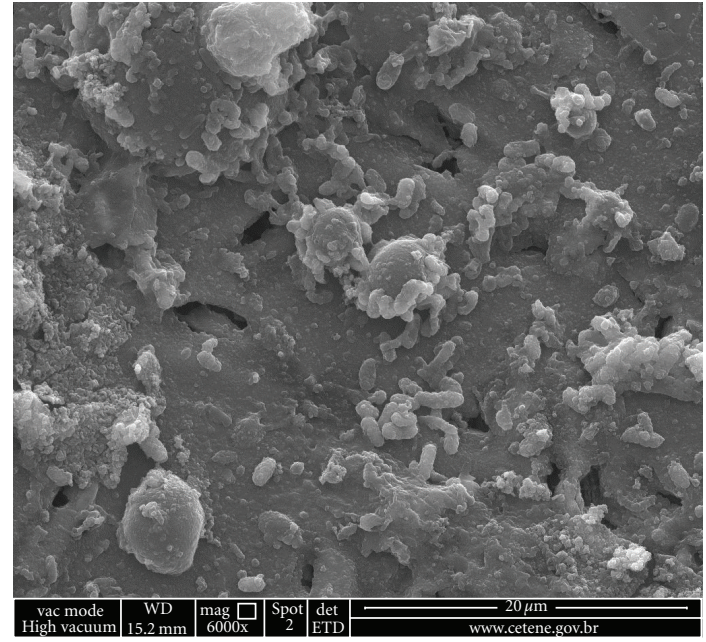

Figure 5: SEM of biofilms formed on AISI-1020 carbon steel, exposed to the fluid water $+30 \% \mathrm{~B} 3$ fuel for a period of 15 days.

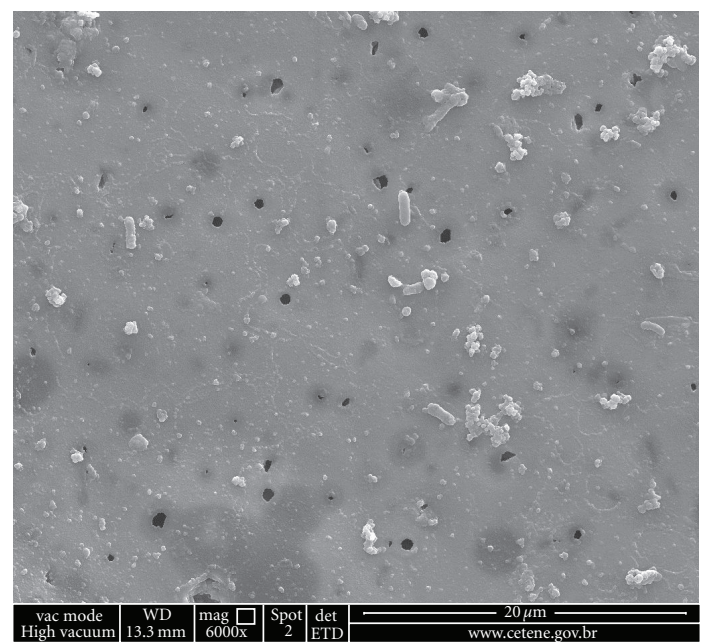

FIgURE 6: SEM of biofilms formed on AISI-1020 carbon steel, exposed to the fluid water $+60 \%$ B3 fuel for a period of 15 days.

In Figure 5, the microorganisms attached to the metal surface can be observed, which confirms the results found in other aqueous systems [12, 17]. Pitting corrosion can be seen in Figure 6.

During the process, the biodegradation of linear C9 to $\mathrm{C} 20$ hydrocarbons was quantitatively verified (Figure 7). These compounds are present in the diesel fraction of the B3 fuel. Practically all of these compounds degraded after 15 days in the $10 \%$ fuel, as can be seen by comparing Figures 7(a) and 7(b).

Studies report that pure biodiesel is highly biodegradable in aquatic and terrestrial environments and that $90-98 \%$ of biodiesel is mineralized between 21 and 28 days in both anaerobic and aerobic conditions at room temperature [18]. Bucker et al. [19] have confirmed the hypothesis that the addition of biodiesel in diesel fuel increases its biodegradability in experiments with various diesel/biodiesel

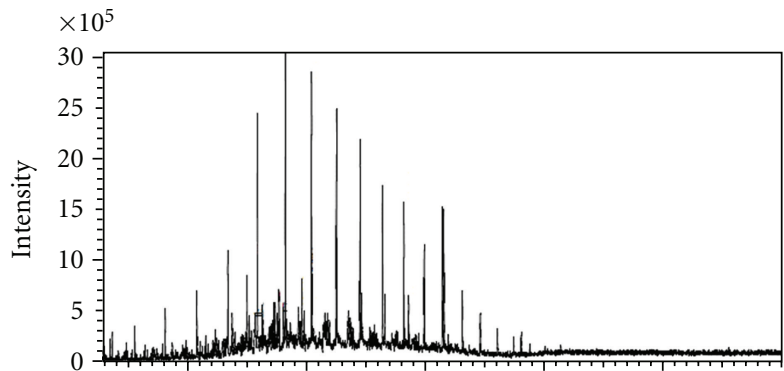

(a)

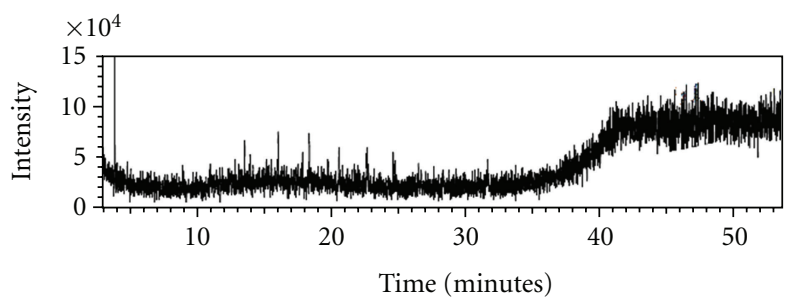

(b)

Figure 7: Aliphatic hydrocarbons detected in the system water + $10 \%$ diesel/biodiesel with gas chromatography. (a) Before the process and (b) after 15 days of processing.

mixtures by studying fungi isolated from contaminated systems.

\section{Conclusions}

The results show that the B3 fuel harbors microorganisms. In experiments with dynamic systems, it was found that the biofilm composition and corrosion of AISI-1020 carbon steel is influenced by concentration of biodiesel in the working fluid. Pitting corrosion was observed when biodesel was supplemented to water and the main corrosion products identified were the various forms of $\mathrm{FeOOH}$, magnetite, and all forms of FexSy. The complete biodegradation of aliphatic hydrocarbons in the diesel present in the B3 fuel was also observed.

\section{Acknowledgments}

The authors would like to thank the Conselho Nacional de Desenvolvimento Científico e Tecnológico (CNPq), the Coordenação de Aperfeiçoamento em Pesquisa e Ensino Superior, the Fundação de Auxílio a pesquisa do Estado do Rio de Janeiro (FAPERJ), the Petróleo Brasileiro SA, the Instituto de Tecnologia de Pernambuco (ITEP-OS), and the Departamento de Engenharia Mecânica (UFPE) for financial support.

\section{References}

[1] R. A. Ferrari, V. S. Oliveira, and A. Scabio, "Biodiesel de sojataxa de conversão em ésteres etílicos, caracterização físicoquímica e consumo em gerador de energia," Química Nova, vol. 28, no. 1, pp. 19-23, 2005. 
[2] V. Gentil, Corrosão, LTC, Rio de Janeiro, Brazil, 6th edition, 2011.

[3] R. Zuo, "Biofilms: strategies for metal corrosion inhibition employing microorganisms," Applied Microbiology and Biotechnology, vol. 76, no. 6, pp. 1245-1253, 2007.

[4] E. S. Torres and F. P. de França, "Performance of foamy PIGS on the removal of biofilms from AISI-020 carbon steel pipelines," Corrosion Reviews, vol. 22, no. 3, pp. 193-208, 2004.

[5] J. R Postgate, The Sulphate-Reducing Bacteria, Cambridge University Press, Cambridge, UK, 2nd edition, 1984.

[6] H. A. Videla, "Prevention and control of biocorrosion," International Biodeterioration \& Biodegradation, vol. 49, no. 4, pp. 259-270, 2002.

[7] M. O. Penna, W. Baptista, R. F. Brito, J. R. Nascimento, and C. M. L. Coutinho, "Sistema dinâmico para avaliação de técnicas de monitoração e controle da CIM," Boletim Técnico da Petrobras, vol. 45, no. 1, pp. 26-33, 2002.

[8] R. C. Miranda, C. S. Souza, E. B. Gomes, R. B. Lovaglio, C. E. Lopes, and M. F. V. Q. Sousa, "Biodegradation of diesel oil by yeasts isolated from the vicinity of Suape Port in the State of Pernambuco-Brazil," Brazilian Archives of Biology and Technology, vol. 50, no. 1, pp. 147-152, 2007.

[9] I. B. Beech and C. C. Gaylarde, "Recent advances in the study of biocorrosion-an overview," Revista de Microbiologia, vol. 30, no. 3, pp. 177-190, 1999.

[10] D. Cetin and M. L. Aksu, "Corrosion behavior of low-alloy steel in the presence of Desulfotomaculum sp," Corrosion Science, vol. 51, no. 8, pp. 1584-1588, 2009.

[11] I. B. Beech and J. Sunner, "Biocorrosion: towards understanding interactions between biofilms and metals," Current Opinion in Biotechnology, vol. 15, no. 3, pp. 181-186, 2004.

[12] F. P. de França and W. B. Cravo Jr., "Variation in sessile microflora as function of flow velocity on coupons exposed to seawater," World Journal of Microbiology and Biotechnology, vol. 16, no. 8-9, pp. 811-814, 2000.

[13] P. R. A. Ambrozin, E. S. Kuri, and R. M. Monteiro, "Corrosão metálica associada ao uso de combustíveis minerais e biocombustíveis," Química Nova, vol. 32, no. 7, pp. 1910-1916, 2009.

[14] R. Stadler, W. Fuerbeth, K. Harneit, M. Grooters, M. Woellbrink, and W. Sand, "First evaluation of the applicability of microbial extracellular polymeric substances for corrosion protection of metal substrates," Electrochimica Acta, vol. 54, no. 1, pp. 91-99, 2008.

[15] H. A. Videla and L. K. Herrera, "Understanding microbial inhibition of corrosion: a comprehensive overview," International Biodeterioration \& Biodegradation, vol. 63, no. 7, pp. 896-900, 2009.

[16] J. Duan, S. Wu, X. Zhang, G. Huang, M. Du, and B. Hou, "Corrosion of carbon steel influenced by anaerobic biofilm in natural seawater," Electrochimica Acta, vol. 54, no. 1, pp. 22-28, 2008.

[17] H. A. Videla, Biocorrosão, Biofouling e Biodeterioração de Materiais, Edgard Blucher, São Paulo, Brazil, 1st edition, 2003.

[18] J. C. Pasqualino, D. Montané, and J. Salvadó, "Synergic effects of biodiesel in the biodegradability of fossil-derived fuels," Biomass and Bioenergy, vol. 30, no. 10, pp. 874-879, 2006.

[19] F. Bucker, N. A. Santestevan, L. F. Roesch et al., "Impact of biodiesel on biodeterioration of stored Brazilian diesel oil," International Biodeterioration \& Biodegradation, vol. 65, no. 1, pp. 172-178, 2011. 

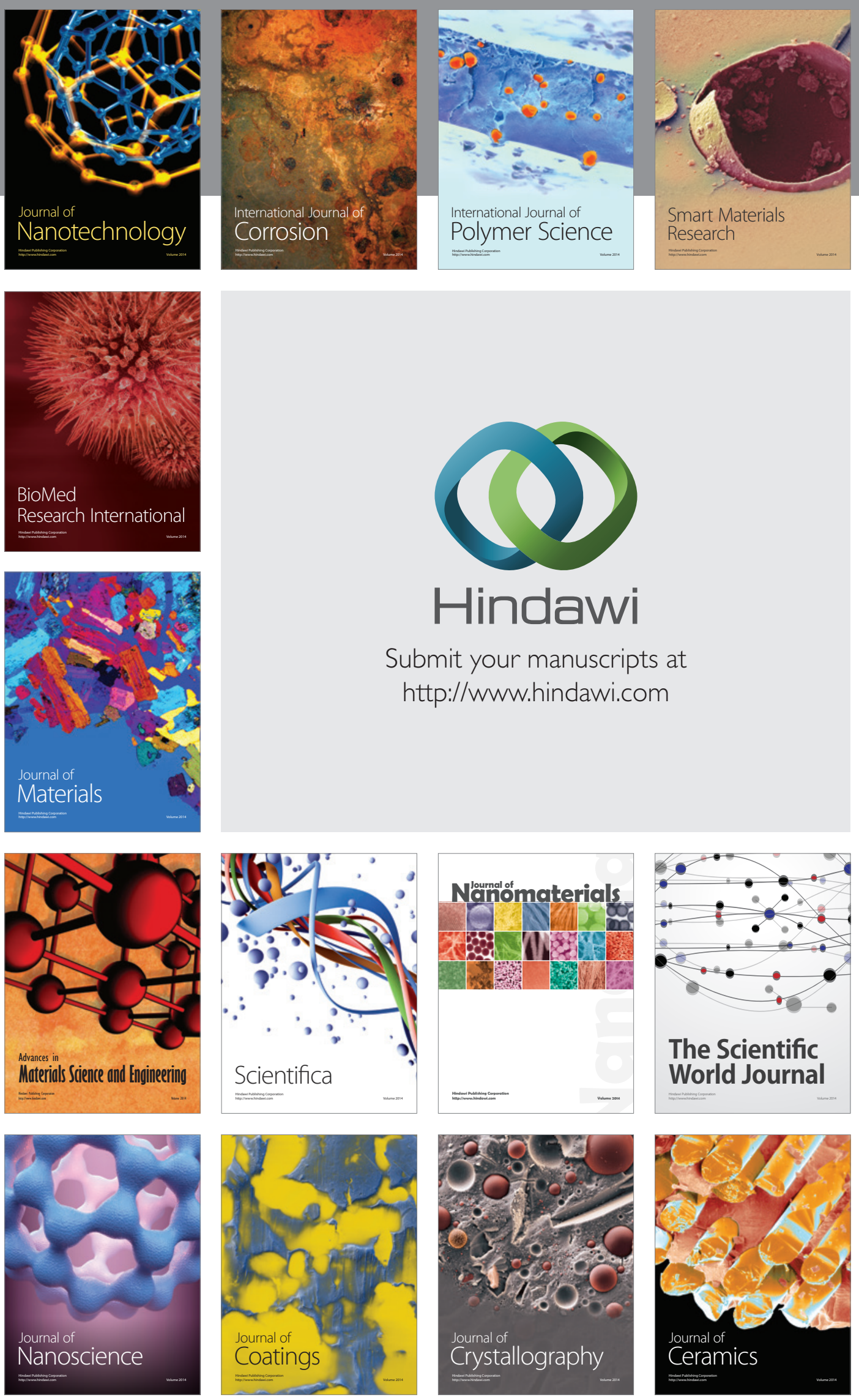

The Scientific World Journal

Submit your manuscripts at

http://www.hindawi.com

\section{World Journal}

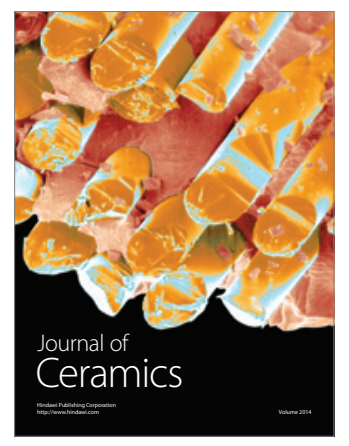

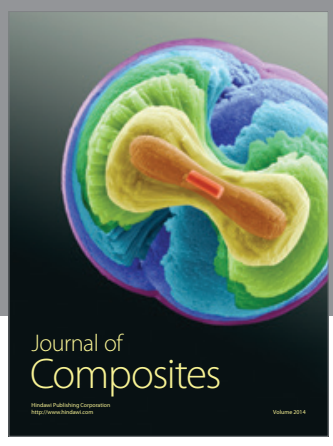
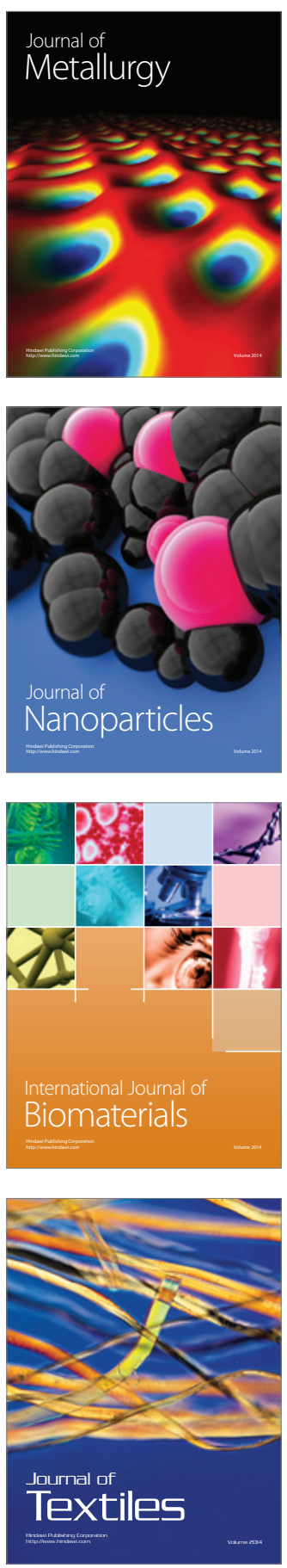